\title{
Peningkatan Peran Serta Suami/Keluarga dalam Mendukung Pemberian ASI Eksklusif di Wilayah Kerja Puskesmas Jekan Raya Palangka Raya
}

Increased Husband/Family Participation in Supporting Exclusive Breastfeeding in the Work Area of Jekan Raya Health Center Palangka Raya

Heti Ira Ayue ${ }^{*}$
Oktaviani
Department of Midwifery, Poltekkes
Kemenkes Palangka Raya, Palangka
Raya, Central Kalimantan, Indonesia
"email: hetiiraayue@gmail.com
Kata Kunci
Peran Serta Suami
ASI Eksklusif
Puskesmas
Keywords:
Husband's Participation
Exclusive breastfeeding
Public health center

\begin{abstract}
Abstrak
Cakupan ASI ekslusif di Kota Palangka Raya juga masih jauh dari target yang ditetapkan pemerintah. Profil kesehatan Kota Palangka Raya tahun 2017 dari 10 Puskesmas induk di Kota Palangka Raya, tiga puskesmas dengan cakupan terendah adalah Puskesmas Jekan Raya (2,58\%), Puskesmas Menteng (6,13\%), dan Puskesmas Kayon (9,42\%). Tujuan dilaksanakan pengabdian masyarakat ini adalah memberikan pendampingan guna meningkatkan Peran Suami dalam mendukung pemberian ASI Eksklusif di Wilayah Kerja Puskesmas Jekan Raya Kota Palangka Raya. Pelaksanaan pengabdian masyarakat dilakukan tiga kali kunjungan kepada sasaran ibu hamil/nifas beserta suami/keluarga.
\end{abstract}

\begin{abstract}
The coverage of exclusive breastfeeding in Palangka Raya City is also far from the target set by the government. Palangkaraya Health Profile in 2017 from 10 main Puskesmas in Palangka Raya City, the three lowest coverage health centers was Jekan Raya Health Center (2.58\%), Menteng Health Center (6.13\%), and Kayon Health Center (9.42\%). The purpose of this community service is to provide assistance to improve the role of the husband in supporting exclusive breastfeeding in the Jekan Raya Community Health Center in Palangka Raya City. The community service was carried out three times to target pregnant/postpartum mothers and their husbands/families.
\end{abstract}

(c) 2020 Heti Ira Ayue, Oktaviani. Published by Institute for Research and Community Services Universitas Muhammadiyah Palangkaraya. This is Open Access article under the CC-BY-SA License (http://creativecommons.org/licenses/by-sa/4.0/). DOI: https://doi.org/10.33084/pengabdianmu.v5i3.1143

\section{PENDAHULUAN}

Air Susu Ibu atau ASI adalah makanan terbaik bagi bayi baru lahir hingga berumur enam bulan. Pemberian ASI secara ekslusif merupakan salah satu program pemerintah untuk meningkatkan taraf kesehatan ibu dan anak (Santi, 2017). Namun demikian, cakupan ASI ekslusif di Kota Palangka Raya masih jauh dari target yang ditetapkan pemerintah. Tahun 2016 yaitu 14,99\% dan pada tahun 2017 meningkat menjadi 16,79\% (Dinas Kesehatan Kota Palangka Raya, 2017; Dinas Kesehatan Kota Palangka Raya, 2018). Berdasarkan laporan profil kesehatan Kota Palangka Raya tahun 2018, dari 10
Puskesmas induk di Kota Palangka Raya, tiga puskesmas dengan cakupan terendah diantaranya adalah Puskesmas Jekan Raya, Puskesmas Menteng dan Puskesmas Kayon, dimana ketiganya berada di Wilayah Kecamatan Jekan Raya. Di wilayah cakupan Puskesmas Jekan Raya, dari 310 bayi yang berusia 0-6 bulan hanya 8 bayi (2,58\%) yang memperoleh ASI ekslusif. Pada Puskesmas Menteng, dari 815 bayi berusia 0-6 bulan hanya 50 bayi $(6,13 \%)$ yang memperoleh ASI ekslusif, sedangkan di Puskesmas Kayon, dari 711 bayi usia 0-6 bulan, 67 bayi (9,42\%) memperoleh ASI ekslusif (Dinas Kesehatan Kota Palangka Raya, 2018). 
Salah satu penghambat pemberian ASI ekslusif adalah praktik pemberian asupan prelakteal (prelacteal feeding) pada bayi baru lahir pada minggu pertama kehidupan sebelum ASI lancar keluar (Amele et al., 2019; Ayue, 2017; Novianti \& Rizkianti, 2014). Penyebab lain adalah rendahnya pengetahuan ibu dan keluarga lainnya mengenai manfaat ASI dan cara menyusui yang benar, kurangnya pelayanan konseling laktasi dan dukungan dari petugas kesehatan, faktor sosial budaya, kondisi yang kurang memadai bagi para ibu yang bekerja, serta gencarnya pemasaran susu formula (Dinas Kesehatan Provinsi Kalimantan Tengah, 2018; Radzyminski \& Callister, 2016; Ambarwati et al., 2013). Berdasarkan uraian diatas dan melihat kecendrungan cakupan ASI eksklusif yang masih jauh dari target inilah yang melatarbelakangi penulis untuk melaksanakan pengabdian kepada masyarakat tahun 2019 dengan judul Peningkatan Peran Serta Suami/Keluarga dalam Mendukung Pemberian ASI Eksklusif di Wilayah Kerja Puskesmas Jekan Raya Palangka Raya.

\section{METODOLOGI}

Metode kegiatan pengabdian dilaksanakan melalui kunjungan rumah ke sasaran pengabdian masyarakat sebanyak tiga kali, kunjungan pertama dan kedua dilaksanakan dengan memberikan konseling menyusui untuk ibu dan suami/keluarganya. Kunjungan ketiga dilakukan untuk mengevaluasi hasil konseling dan pendampingan ASI ekslusif pada sasaran. Kunjungan ketiga dilaksanakan setelah masing-masing bayi berumur enam bulan.

\section{HASIL DAN PEMBAHASAN}

Konseling dilakukan dengan metode mendatangi ke rumah sasaran pengabdian langsung dengan tujuan untuk memastikan kepatuhan target sasaran untuk mengikuti tahapan konseling hingga selesai.
Pelaksanaan konseling dilakukan dengan panduan sebagaimana tercantum dalam moledul yang dikeluarkan oleh Perkumpulan Perinatologi Indonesia atau Perinasia (2012). Setelah diberikan konseling dan pendampingan kepada lima ibu hamil/nifas beserta suami/keluarga tersebut, sebanyak tiga dari lima ibu $(60 \%)$ berhasil menyusui bayi secara ekslusif sampai dengan bayi berusia enam bulan. Hasil pengabdian kepada masyarakat ini juga selaras dengan penelitian Kusumayanti dan Nindya (2017) yang melaporkan bahwa ibu yang mendapat dukungan suami lebih besar peluangnya $(27,1 \%)$ terhadap pemberian ASI eksklusif dibandingkan suami yang tidak mendukung $(5,6 \%)$. Dengan kata lain, dapat disimpulkan bahwa ibu yang mendapat dukungan dari suami memiliki proporsi yang lebih besar memberi ASI eksklusif dibandingkan dengan yang tidak mendapatkan dukungan suami (Oktalina et al., 2015). Visualisasi ASI perah dalam botol ditunjukkan pada Gambar 1, sedangkan dokumentasi kegiatan konseling disajikan pada Gambar 2.

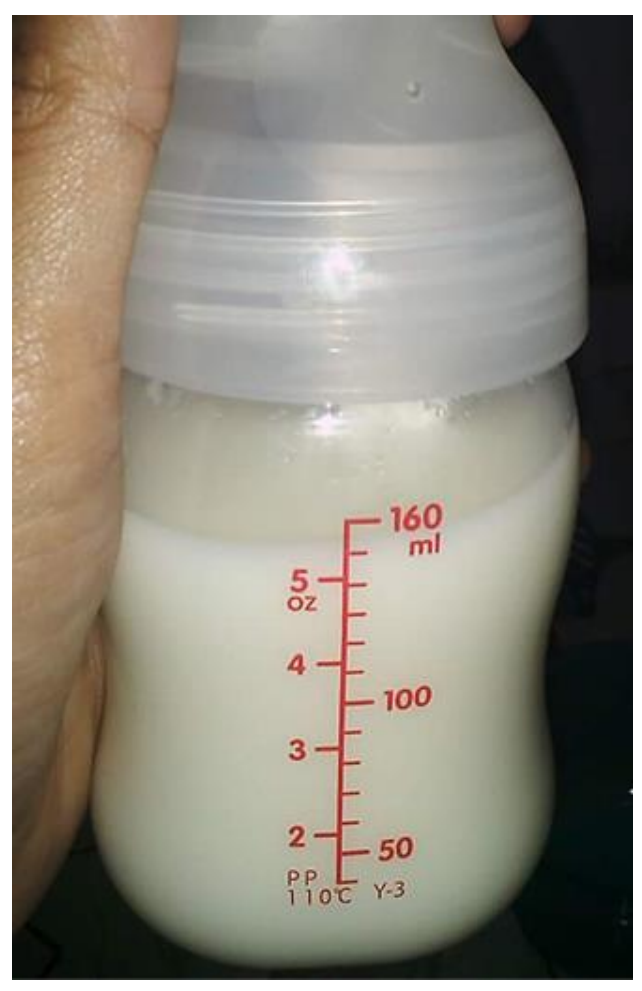

Gambar 1. ASI Perah yang diberikan saat ibu bepergian/bekerja untuk mencegah pemberian penganti ASI yaitu susu formula 


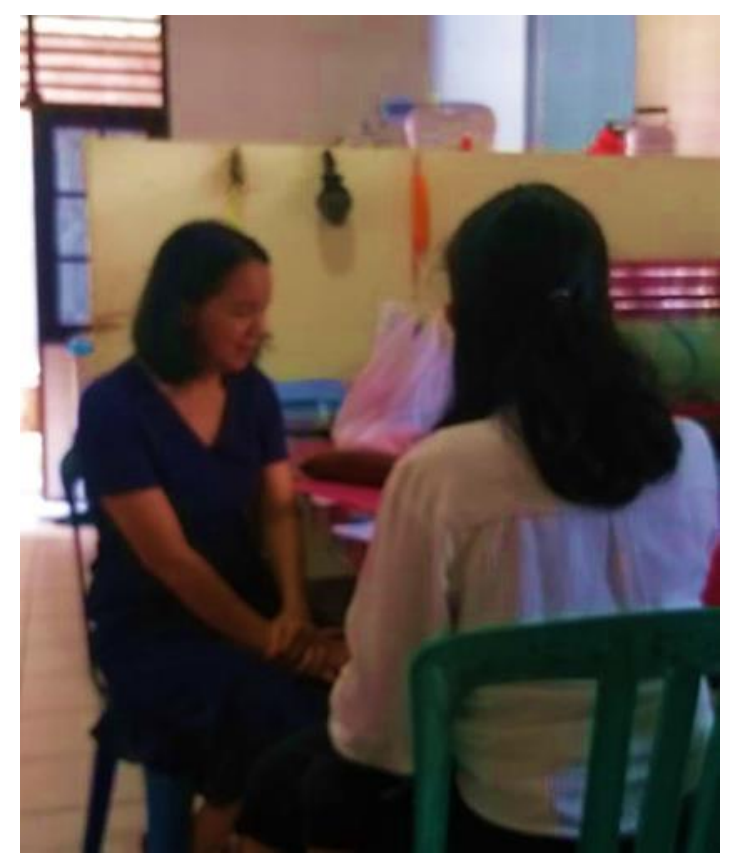

Gambar 2. Proses Konseling menyusui

\section{KESIMPULAN}

Ibu beserta suami/keluarga yang menjadi sasaran pengabdian masyarakat telah dibekali pengetahuan tentang ASI ekslusif serta telah diberikan konseling dan dimotivasi agar hanya memberikan ASI ekslusif kepada bayi hingga berusaia enam bulan. Tiga dari lima atau $60 \%$ dari sasaran pengabdian masyarakat telah melaksanakan ASI ekslusif sampai bayi berusia enam bulan. Pengabdi juga menyarankan optimalisasi persiapan pemberian ASI ekslusif perlu ditekankan sejak ibu hamil dan dilanjutkan pendamping pada masa nifas, pelaksanakan kelas ibu hamil perlu dilaksanakan secara teratur yang didalamnya pembekali ibu hamil, suami/keluarga pengetahuan tentang ASI ekslusif, dan perlunya pengabdian masyarakat lanjutan untuk meningkatkan pengetahuan dan pelaksanaan pemberian ASI ekslusif.

\section{UCAPAN TERIMA KASIH}

Terimakasih dan penghargaan kepada Kepala Dinas Kesehatan Kota Palangka Raya dan Kepala Puskesmas
Jekan Raya yang telah mengizinkan pengabdian kepada masyarakat ini dilaksanakan di wilayah kerjanya.

\section{REFERENSI}

Ambarwati, R., Muis, S.F., Susantini, P. 2013. Pengaruh konseling laktasi intensif terhadap pemberian air susu ibu (ASI) eksklusif sampai 3 bulan. Jurnal Gizi Indonesia (The Indonesian Journal of Nutrition). 2(1):15-23. https://doi.org/10.14710/jgi.2.1.

Amele, E.A., Demissie, B.W., Desta, K.W., Woldemariam, E.B. 2019. Prelacteal feeding practice and its associated factors among mothers of children age less than 24 months old in Southern Ethiopia. Italian Journal of Pediatrics.

45:15. https://dx.doi.org/10.1186/s13052-019-06043

Ayue, H.I. 2017. Tingkat Pengetahuan Ibu Menyusui: Studi Komparatif di Kabupaten Kapuas dan Katingan Provinsi Kalimantan Tengah. Palangka Raya: Poltekkes Kemenkes Palangka Raya.

Dinas Kesehatan Kota Palangka Raya. 2018. Profil Kesehatan Kota Palangka Raya Tahun 2017. Palangka Raya: Dinas Kesehatan Kota Palangka Raya.

Dinas Kesehatan Kota Palangka Raya. 2017. Profil Kesehatan Kota Palangka Raya Tahun 2016. Palangka Raya: Dinas Kesehatan Kota Palangka Raya.

Dinas Kesehatan Provinsi Kalimantan Tengah. 2018. Profil Kesehatan Provinsi Kalimantan Tengah Tahun 2017. Palangka Raya: Dinas Kesehatan Provinsi Kalimantan Tengah.

Kusumayanti, N., Nindya, T.S. 2017. Hubungan Dukungan Suami Dengan Pemberian Asi Eksklusif di Daerah Perdesaan. Media Gizi Indonesia. 12(2):98-106. http://dx.doi.org/10.20473/mgi.v12i2.98-106

Novianti, N., Rizkianti, A. 2014. Pemberian Asupan Prelakteal Sebagai Salah Satu Faktor Kegagalan Asi Eksklusif Pada Pekerja Buruh Industri Tekstil Di Jakarta. Jurnal Kesehatan Reproduksi. 5(1):23-36.

Oktalina, O., Muniroh, L., Adiningsih, S. 2015. Hubungan Dukungan Suami Dan Dukungan 
Keluarga Dengan Pemberian ASI Eksklusif Pada Ibu Anggota Kelompok Pendukung ASI (KP-ASI). Media Gizi Indonesia. 10(1):64-70. http://dx.doi.org/10.20473/mgi.v10i1.64-70

Perinasia. 2012. Pelatihan Konseling Menyusui Modeul 40 Jam (Standar WHO/Kemkes/UNICEF). Jakarta: Perkumpulan Perinatologi Indonesia.

Radzyminski, S., Callister, L.C. 2016. Mother's Beliefs, Attitudes, and Decision Making Related to Infant Feeding Choices. The Journal of Perinatal Education. 25(1):18-28. https://dx.doi.org/10.1891/1058-1243.25.1.18

Santi, M.Y. 2017. Upaya Peningkatan Cakupan Asi Eksklusif Dan Inisiasi Menyusu Dini (IMD). Kesmas Indonesia: Jurnal Ilmiah Kesehatan Masyarakat. 9(1):77-90. 